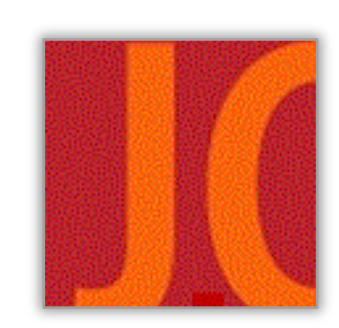

\title{
Walking Meditations: Becoming Place, Place Becoming
}

\author{
Alexandra Fidyk \\ University of Alberta
}

\begin{abstract}
:
Interwoven through four lyric snapshots of haptic relations with place-Saskatchewan, New York, South Africa and Egypt-this philosophic rumination considers the primacy of preconscious bodily feeling to learning. Perception at base level is described as synaestheticthe whole body sensing and moving in relation to agential landscapes. The entangled snapshots embody inter-multi-sensorial experience so to mirror the ways our bodies exist in relation to things seen and unseen. Together, the two texts, two voices, step in support of walking pedagogies as a profound praxis in service to becoming, an unfolding always underway with place, even distant and unfamiliar. Highlighted as embodied and explored, matter central to an earthly curriculum are the methods of slow, attuned, disciplined attention and somatic resonance.
\end{abstract}

Keywords: synaesthesia; walking pedagogy; bodily feeling; place; animated; attention; attunement 


\title{
Les Méditations à pied : devenir en place, en place devenir
}

\author{
Résumé : \\ Entrelacée à travers quatre instantanés lyriques des relations haptiques avec le lieu-la \\ Saskatchewan, New York, l'Afrique du Sud et l'Égypte-cette rumination philosophique \\ considère la primauté du sentiment corporel préconscient sur l'apprentissage. La perception au \\ niveau de base se décrit comme synesthésique-le corps entier ressent et bouge en relation \\ avec des paysages agentiels. Les instantanés enchevêtrés incarnent une expérience inter-multi- \\ sensorielle afin de refléter la façon dont nos corps existent par rapport aux choses vues et \\ invisibles. Ensemble, les deux textes, les deux voix, appuient les pédagogies de la marche \\ comme une praxis profonde au service du devenir, un déroulement toujours en cours avec le \\ lieu, même lointain et inconnu. Les méthodes d'une attention lente, harmonieuse et rigoureuse, \\ et de la résonance somatique, sont au cœur d'un programme terrestre.
}

Mots clés : la synesthésie; animé; les corps; l'attention; I'harmonisation; la résonance; le sentiment 
Tell me the landscape in which you live, and I will tell you who you are.

(Ortega y Gasset, 2011, p. 1)

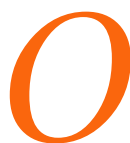

ur sensory systems intra-act-holon within holon. Our bodies pulse in spontaneous convergence with things encountered-seen and unseen. Things, bodies that surround, are not inert, passive objects. Rather, they are expressive entities, powers and potencies, with whom we exist-"intra-acting phenomena" that are the "ontological inseparability of agentially intraacting components" of the world (Barad, 2003, p. 815). A "throb of experience" (Whitehead, $1929 / 1941$, p. 190), of here-now and there-then, where one forms from the many, an Iemerges from a we. A subject from a world of others while always in relationship with them-a subject that is object to the creative beat of becoming.

This process between our bodies and other bodies of the world-circling an old pine in walking meditation, for instance-is reciprocal and dynamic, an intra-active, enfolded entanglement. Such circling in place animated my sensations, feelings, images, and thoughts, which, in turn, I attended; these same sensations, feelings, images, and thoughts, animated the pine, grasses and roots on which attention was bestowed. The movements of this process - "inward to facets of the self, outward towards aspects of the external world, alternately both together" - transpire in the immediacy of the moment (Basso, 1996, p. 55). An interpenetration that cannot occur in advance of walking, it is a turning borne of preconscious body feeling dispersed into sensorial experience. The challenge of "coming to our senses" (Kabat-Zinn, 2005), both individually and as a species, in education and beyond, is an ethical act that confronts us all. By ethical, I mean a pedagogic response-ability with self and other, the other that is muskeg, sand and sea.

Omega Institute, Rhinebeck, NY Monday, June 6, 2010

An aromatic cushioned forest floor pushes back against the soles of my feet. Padded with needles, molten leaves and crusty lichen, the gnarled roots of the old pine cup the curve of my instep in one movement and tip me in the next. It is day two of a seven-day mindfulness meditation retreat, and I have been contemplatively circling this old tree. Slow. Disciplined. Attuned. Sole touch.

Unexpected humidity chills my spine. I shiver. Together, they steal my attention and I constrict. Instinctively, I move closer to the sturdy trunk as it radiates heat, warmth conserved from yesterday's rays. This is not prairie June.

Synaesthesia is an ancient Greek term of syn (together) and aisthesis (a physical feeling or perception of something in conscious contact with the body, something sensed via the body). It is 
used here to identify an unbidden, active, unified experience of different senses-including sense of movement or proprioception, equilibioception, thermoception and chronoception (see activity "Synaesthesia Walk," Judson, 2018). Perception at the primary level is synaesthetic - "an affair of the whole body sensing and moving" (Casey, 1996, p. 18), never entirely a matter of "receptivity" (Kant cited in Casey, 1996, p. 18). Bodies in relation are not simply passive. Akin to wu-wei, to perceive synaesthetically is to be actively non-active; "to be absorptive yet constitutive, both at once" (Casey, 1996, p. 18). Writing our sensory perceptions as singular acts-see, hear, taste-feels artificial; while we can speak of them as separate senses, at the same time, we also have one undivided experience.

We are taught in school from a very young age about perception in relation to one of the five senses, and we forget that we do not actually experience the world this way. In the adult privileging of abstraction, categorization, interpretation and language, children are trained to sever their immediate, embodied worlds for mathematized learning. They become unrooted from their familiarity with the world in service to measurable, repeatable, predictable instruction. The methodical severances of our sensuous familiarity with the world displace both the object, which no longer can be located, and the subject, which no longer understands through relationship. And yet there is no easy differentiation of subjectivity and objectivity, and everything in between (see Püschel, 2017). Without that old pine, I cannot speak meaning-fully of my walking meditation or what I learned during the retreat. The act of severing my bodily experience from the perceptual particulars of place, that tree, leaves me adrift.

The commonly used procedures of objectification protect us from the alluring calls and consequences of moments that strike us, ask something of us, reawaken us to the world. We need not worry about unanticipated, unplanned-for interchanges with the world when the possibility of understanding beckoned by something unbidden and without methodical anticipation is eliminated (Jardine, 1998). So we reside in the security and predictability of curriculum-as-planned and teacheras-technician.

The very act of severance, which cuts away the tangled ambiguity of the evocative given, mirrors the act of separation inherent in the privileging of one sense over the composite nature of the initial primordial bodily encounter. The experiencing body is not a self-enclosed object, but a porous, incomplete entity, fluxing in and out of form within a purposeful pluriverse-itself, intimate, subjective and rooted. An over-place of non-dual interconnectedness and animation in which we are all kin. Such openness is evident in the arrangement of the senses. We have numerous ways of encountering and exploring the world-touch, taste, balance, movement and haptic sensibilities. All of these pathways reach from the perceiving body.

Fish Eagle, Monkey Valley Resort Noordhoek, South Africa April 2011

We are exhausted yet perk up when we hear joyous laughter, local banter, Cape jazz, township Mbaqanga, and Zulu maskandi music wafting on night air. 
We exit the airport. Everything is sticky.

We shed layers as our bodies acclimatize to the 60 degree temperature change traversed over 36 hours of flight.

We load the rental car and take $\mathrm{N}-2$ through black townshipscommunities relocated, impoverished by colonial rule, violence, and segregationlocked-in place, as if time and political leadership have not changed since oppressive Afrikaans rule.

We turn left at the fork, De Waal Drive (aka Blue Route); head south, hugging the foot of majestic Table Mountain, sliding into thick fog. We drop down onto the Cape Flats-the Southern Suburbsa road that divides two social classes: middle and working classes to the left, wealthy and entitled to the right (Newlands, Bishops Court, Constantia) winding back up and over Ou Kaapse Weg (Old Cape Road) along the mountain.

We glide through heavy darkness, on what has become familial roads. Blind to the details, I feel what is there-low fynbos shrubs (fine bush), orange watsonias, bright red Ericas, wild proteas, and rugged sandstoneas we move steadily closer to our house and Noordhoek (North hook village). A valley that long before this was occupied by the nomadic, pastoral Khoikhoihunting-gathering Indigenous peoples of southern Africa. Condensation encapsulates us; the windshield fogs over.

Balance temporarily lost.

When driving from the airport to the house, place had become hapticality known; I felt the temperature-time-rock-taste of sea in my body as a unitive experience. Despite the car moving through the night, it was a deeply embodied encounter: it was my body, moist in fog, sirens and dogs in my ears, brush of bush on my arms. In actuality, we perceive an integral sensorial-image or gestalt of the elements, and it is only upon selective attention that we separate out the details of colours, sounds and figures. Over years of practice to build my capacity for presence, fuller arrangements of emplaced, haptic, and affective sensorial elements have returned to my lived experience. Too, I have found that intimacy with place, via slow, attuned and disciplined, attention, has aided to draw vibrational matter into consciousness.

This understanding may have been the impetus to stop the vehicle in the Great Sand Sea. I craved its immediacy. I had a sense of the dunes' size through spacial appearance from inside the vehicle, but once I ran-tasting wind, salt, grit; feeling sand with my flesh, pores constricted in heat, wind, movement; touching with my face and feet-I had a felt sense of space. Intimately taking in the desertscape details transformed its spacial feeling. It too is porous, emergent. Bodily movement produces the experience of space. Rooted in the deepest and subtlest recesses of the lived body, a reliable and persisting "anchorage" in the world exists; we are held in-place (Merleau-Ponty, 1962, p. 387). From this original footing, feeling the desert by running granted an intensified intrasensorial transspecies experience of its grandeur. Reciprocally, my sense of self shifted. Simultaneously and paradoxically, I felt shrunk-down and spread-out. 
As we moved silently among headstones at the war cemetery in Alamein, a haunting chilled my arms. Despite the sun's warmth, I needed a sweater. 814 unidentified burials. 8500 dead. Even in death, there is no independent existence. No borders here between those who served and died in Syria, Lebanon, Iraq and Persia-and who arrived from Australia, Canada, Britain, South Africa, New Zealand, India, and the US.

Up early, we travel Highway 40 along the coast, drop southwest into the Great Sand Sea.

Mile after mile of amber drifts, ripples of heat glide across the road, spreading out in every direction. Excited, I lean and squint to ensure that the images in the east are camels. Their distinct bulbous bodies and slink necks repeat the elongated rocking that I associate with their gait.

Committed, they sway steadily along the horizon, a ribbon waving. We pull off the track, petrified by wind and heat. I need to feel the sand; I need communion.

Driving in the Great Sand Sea and driving up and around Table Mountain were two unique somatic encounters, yet both assembled transcorporeality. In the first, it was my initial contact with the desert, and I was coming-to-know through a process of being-in-relation-with-sand-seadespite, it always already having expressed itself upon me. However, neither of us had yet affected the other in a conscious way. In the second, the mountain and I have had direct acquaintance. We had become devoted to each other's concreteness, even from afar. After living in it annually for short durations across more than a decade, intimately, it was of me, and I was of it. We were conjoined in a process of "emplacement" (Casey, 1996, p. 24).

As discovered in the Great Sand Sea, the body's active engagement with place is most evident in walking-moving in relation to sandscape. A scape that actively solicits motion, thought and feeling. A vehicle can be a form of walking in the same way that glasses serve to extend the eyes. When the vehicle, as body container, falls away from consciousness, it enables the person to come into direct relation with the environment via embodied presence, not unlike a robotic limb or wheelchair. It is never only the foot in contact with the gnarled roots of the pine but a kinesthetic, synesthetic and sonaesthetic whole. Too often, walking research privileges ableism, denying an affective experience via limb, ability or sensory difference. When we have varying or limited use of one or more senses, others become heightened, cross-connected. Certainly, if one is not consciously embodied, but fragmented or dissociated, then moving in a vehicle will be a qualitatively different experience.

My weight breaks the crest of the first dune. Sand drifts fracture like snow drifts. Golden honey or gleaming crystal, there is little difference. I have no aim and run into the sea's vastness. 
A kid, I lift my arms, turning this way then that, climbing then falling down the dunes.

Glee falls short when my runners break through again and I sink to my calves.

I pull one foot free yet drop farther with the other.

I run-on, call-out-will there be an echo? My voice, liquid, evaporates in the heat. Soon the dunes cease.

I descend with every step.

Loose and unforgiving, grains flood immediately around each foot, grabbing-hold before I can extricate them. Every trace of my intrusion removed.

Untethered, linear crests run-on, called by the moon.

We wake, crawl from the belly of the mountain into sharp morning light, low turquoise sky, and a raging Atlantic Ocean.

Barefoot, coffee in hand, I step through open glass doors into the harsh, primitive beauty of the Cape.

Hoopoes, yellow-breasted Cape siskins, the elegant pin-tailed whydah, and gentle Cape sugarbirds greet me-at least look and appear undisturbed.

They peck and eat, scratch and hop. Hadedas are around too-

their three to four note calls broke through my sleep, a reminder that I would not wake to snow.

Scissor-hand aloes, delicate fynbos, precious sugarbushes, and indigenous milkwoods sing in beauty.

Lavender, olive tree, and geranium bushes flower madly in purples, whites, and pinks. My skin drinks. I join a vibrant parade of green-jade, emerald, forest, fern, moss, pear, pickle, basil, and parakeetand my body softens. My toes deliciously spread-out, circle, respond to the springy earth-covered kikuyu grass, a soft, broad-stemmed sun-loving species that cushions my stand and parts my toes.

Weight held in my shoulders drops to my soles. The sensorial particularities of this mountain home seep in.

There is no division.

Attunement, resonance, somatic empathy, even a sense of safety, occur only when we breathe present and embodied. By fragmentation and dissociation, I mean a disembodied state. Fragmentation points to partial consciousness regarding the dynamic tension between egoic awareness and unconscious material. When the degree of unconscious material increases, completely encapsulating the ego, where no "I" or even "sub-I" appears, this is a dissociative state. During times of fragmentation and more so when dissociated, perception and memory become limited, even skewed. These states markedly impact learning. Walking, attentively, returns us to embodiment. 


\section{Walking Meditations}

Earthly curriculum, then, becomes vital to the quality of our relations. Such a profound shift can unearth a new ethic. Sensing places, being-of-place, settled and nomadic, animates ideas and imaginings to attend to them - an ethic imbued with respect and relational accountability. "Sensing places, they dwell," as Basso (1996) describes, "on aspects of dwelling" (p. 55). Our moving and perceiving bodies draw-in images and ideas lodged in place, bringing sensorial aspects together "in the very action of the involvement with the environment" (Ingold, 2000, p. 262). To privilege walking (moving) as method encourages conscious attendance, a kind of corporeal intentionality, and readies the ground for love. A process of "interanimation" (Basso, 1996, p. 55). When we attend, we befriend our own attention, "an intentional, unapologetic discriminator" (Horowitz, 2013, p. 12) - giving itself over to feeling and action. While the art of seeing must be practiced, it comes quickly when coupled with the method of slow. Breathe; ground; attend. For Weil, "attention is the rarest and purest form of generosity," a spiritual act, "prayer" (Weil, 1947/1999, p. 117). It transforms attender and attendee. Attention, for her, is the beginning of education.

Winged kernels press sharp into the underbellypale, soft, sensitive arches, unaccustomed to close contact. Sticky now with resin. It is my heels that are protected, thick pads of dead skin from city-dwelling. Here I roll from the balls to the heels of my feet. A shift that occurs through meeting, through touch.

Needles, green and bundled, host intimately, as they first give-way, then push back from my pressure.

They gift a spring to my step. Air-borne temporarily. Cones, woody and hooked, show no mercy. When wet with pitch, they attach and break my stride.

This tree has much to teach me.

Shakespeare effectively dramatized the symbiotic relationship between the four humors: yellow bile, black bile, phlegm and blood, and the four elements: fire, earth, water and air, which, in turn, correspond to the four seasons (Gallagher, 1993). A parallel exists in the vision quest, a journey through the outer realm to find the inner realm, which in turn reveals the path to take when returning to the outer world. A spiritual wayfinding by walking that demonstrates inherent knowing of the cosmos. More profoundly, this journey illustrates a poetic rendering of many First Nations' abiding belief that "'there is no contrast of the natural and the spiritual, and there is no geography without history and meaning. The land is already a narrative - an artefact of intelligence-before people represent it'" (as cited in Lippard, 1997, pp. 15-16, emphasis added).

Treaty 6 Territory, miyo-wâyahcâs; Cree: pleasant little valley (Ogg, 2020) NE25'42'18-W2 Rural municipality of Pleasantdale, Saskatchewan Spring 1984

Dad left the fencing pail, complete with fencing pliers, nails, insulators, and hammer, on the step. 
In actuality, it's an old red and white honey pailtin, narrow-mouthed, rusty and dented with a sturdy wire handle.

Beside it waits a spool of wire to splice or repair the fence. He's also generously left his cloth-backed, leather work gloves.

Too big for me-

dwarfing my hands, the well-worn fingertips fold overbut they will protect my palms against stubborn, steel wire.

With pail and wire in hand, crossing the hummocks that thickly populate the muskeg, make balance a feat.

The damp, earthy smell enlivens. I leap quickly from one hummock to the next. They loom ahead of me, a swamp of monstrous mushrooms. During spring, covered in sphagnum moss, they are soft, spongy, and slippery. My foot slips but I still my motion and land on anotherquick not to fill my boot with swamp water, peat and cow manure. In places, unturned slough grass and cattails stand waist high. As I near more solid ground, buttercups yellow the outer edges of the slough, and a male mallard waddles swiftly out, demandingly quacks, bidding me to follow. His

mate concealed, busy nest-building. Sharp, bitter, the scent of slough grass begins to dissipate, along with it, the rich, moist, organic life, palpable in the air.

The experience of intra-penetration stands central to both walking-based pedagogies and walking practices (Anderson, 2004; Irwin, 2006; Ingold, 2010; Pink, Hubbard, O'Neill, \& Radley, 2010; Feinberg, 2016; Judson, 2018; Springgay \& Truman, 2019). "Walking . . . allows us the opportunity to be influenced by nature and gain an attitude of respect for all life forms not just human life" (Fulton, 2010, p. 9). It is a "practical way of worldmaking" (Irving, 2010, p. 24). As Feinberg (2016) describes, "attuned interaction with the environment while walking can build a pathway towards convening with the extraordinary in the ordinary" (p. 148). With reference to her own walking-based research and in agreement with Irwin's claim, Feinberg adds, "this type of concentrated involvement with the environment" (p. 151) reinforces what Irwin (2006) describes as "a deeper understanding of selfcreation through an active pedagogy of self" (p. 75; Feinberg, 2016, p. 151). Selves (not egos) in continuous unconscious and sometimes conscious acts of self-composition, compose themselves through the "withness of the body," that is, kinaesthetic awareness in relation with the "circumambient world" (Whitehead, 1929/1941, p. 81). Self-composition flows from feeling-ourbody-feeling-the-world where the body is "only a peculiarly intimate bit of the world" - a particular pulse of the cosmos (Whitehead, 1929/1941, p. 81). Each step taken bears the "heaviness of the entire past-from my immediately contiguous [sic] past to the reaches of a collective unconscious, but not as dead weight .... Rather [an inheritance that] comes always already leavened by the possible" (Keller, 1986, p. 237).

On sandy loam, I pay less attention to where I step, and notice the mumbled tuk of robins. 
The distinct, sharper call and response chatter of the red-winged black bird steals the foreground as butterflies flit among the buttercups.

I check posts, insulators and wire, while keeping an eye on the Charolais, a French breed of taurine beef cattle, in opulent tones of ivory and alabaster. They ruminate through the new greens of the pasturebrome grass, alfalfa, black medic (legume), crested wheat grass, and dandelionseach their own hue and texture.

Happy to roam, the cows saunter, fresh on pasture, after a long winter of hay and dry feed. My boots trample native forage grasses too close to the wire.

Stomp and slide on their fresh stalks and grind my heel into their roots.

Whitehead conceived of bodily feeling as ongoing flows of energy that connect the world with us on a preconscious level, making possible the conscious experience of emotions, desires, and mental activities. For Whitehead (1929/1941), bodily feeling, like undivided sensory perception, is the basic "stuff" of the universe, the most concrete aspects of an ongoing process of becoming (p. 108), "the process of 'feeling' the world, of housing the world in one unit of complex feeling" (p. 80, emphasis in original). At this primordial level of relations, no consciousness is possible. These raw connections of the cosmos are unconscious. Consciousness (ego) differentiates out of feeling or awareness at a later time in the self-creation of the momentary subject, a phase based on the complex contrasts between different feelings, the real and the possible. Bodily feeling, like synaesthesia, is epistemological, cosmological, and pedagogical. Whitehead (1929/1957) writes of bodily feeling: "The connections between intellectual activity and the body, though diffused in every bodily feeling, are focussed in the eyes, the ears, the voice and the hands" (p. 50). While there is a close relationship between the intellectual activity of utilizing an idea and the body, the body is primary because it both knows the world through its perception and communicates back to the world in a direct and concrete way, whether in song, dance, photomontage or quilting.

I survey the 360-degree view of garden, mountain, valley of stables, village and sea. A tattered red flag flies at the shark lookout. With binoculars from the tripodalready positioned to monitor the surf-I look out to sea but cannot decipher it. Neither my heart nor my ear has learned to read tides, waves, or the life teeming beneath the sea's steely-blue surface.

This force remains foreign to me, assaults my body with its cutting cold and mysterious underworld. I grew up with northern freshwater lakes, fought leaches and algaeno preparation for here. This is not the soft Pacific in summer, not languid Vancouver or Santa Barbara beaches. Rather, like glass shards, this ocean rakes against you.

Whether sea, wind, heat or dangernot only puff adders and cobras, but thugs-all kill. 
down the winding mountain road, under the milkwoods, through the forest of wattle and rooikrans.

Soles in touch with sand and root.

Senses are "complementary powers evolved in complex interdependence with one another" (Abram, 1996, p. 61) - the way colour exists within a radiant prism of light. Our primordial, preconceptual experience is inherently synaesthetic_-"the rule" (Merleau-Ponty, 1962, p. 229). "We are unaware of it only because scientific knowledge," privileged still by western systems of education, "shifts the center of gravity of experience, so that we have unlearned how to see, hear, and generally speaking, feel, in order to deduce, from our bodily organization and the world" (Merleau-Ponty, 1962, p. 229, emphasis added). Our ordinary vision arises from a blending of two unique vistas, two perspectives, two eyes. Two sides of the body each with its own access to the visible, yet only in their convergence do we have access to the depth of the visible world. Vision, itself, illustrates a form of synaesthesia (Abram, 1996).

An earthly curriculum of entangled order must have this depth of vision-near and far, immediate and lasting. Where attending kikuyu grass and an euphony of notes-at our mountain home in Noordoek-encourages a silent conversation to flow below, and independent of, my verbal awareness. Attuned presence reveals a "wordless dance always already going on - [an] improvised duet between my animal body and the fluid, breathing landscape that it inhabits" (Abram, 1996, p. 53). Animals too, "in a constant and mostly unmediated relation with their sensory surroundings, think with the whole of their bodies" (Abram, 2010, p. 189).

At times I stop, intoxicated by the sensuous particulars of place, of pasture. These 1500-pound beauties, misunderstood by many, bond and form strong, life-long friendships. When I was a kid, many in the herd were named, and their offspring would carry a name with the same first letter as their mother. We tracked their matrilineal heritage, and, if truth be told, their temperaments, because naming was often associated with the way we perceived their moods and behaviours. Cows sulk, hold grudges, play games, have preferences, and possess incredible memories, akin to elephants.

A powerful matriarchy.

Spring calves are especially endearinglittle mounds of bovine babies scattered through the pasture. An ear or tail twitch here and a buck over there. In their secure containment, they frolic, side-hop, nudge, cuddle, and rough-house. All while under the watchful eye of the crèche-babysitter cowthe last one left nursing her calf becomes designate to watch the young herd until it is feeding time again.

She is their safekeeper.

There has been increasing attention to arts-informed methods and understandings within education, as well as to sensory ways of knowing in other disciplines. Heyrman (2005) argues that in the arts, the "search for correspondences and complementarities between the senses is essential" 
(n.p., abstract) and "the synesthetic experience [becomes] something to be shared" (n.p., conclusion), communicable and blended with personal vision. Similarly, van Campen (2009) writes that children across cultures have lived experience of synaesthesia and many experience music to have colours, tastes or smells (p. 9). Despite these facts, children's awareness, in general, is pruned to a few intersensory connections once they start school. Cognitive skills such as writing and calculating take precedence in learning, and there is little to no attention paid to exploring bodily feeling or sensory phenomena. As select and privileged ways of knowing, doing and expressing become increasingly important in school years, where good grades must reflect such conformity, youth refrain from discussing experience that does not belong within the frame of five senses.

In recent years, research has found the experience of conscious synaesthesia to be quite common as a lived experience. For many musicians, colour often accompanies sound (Abilene, 2018), for others, days of the week and months of the year are coloured (Mencher \& Cytowic, n.d., p. 3). For visual artist David Hockney, who shifted from "silent painting" to painting opera sets, music comes with a certain weight, shape, colour and mass (as cited in Mencher \& Cytowic, n.d., p. 2). For him, music - the melody, not the key, timbre of instruments or actual notes-shapes "the spaciousness of a color" (p. 2). Synaesthesia occurs often in the visually impaired, but also among artists, performers, and composers, such as Eddie van Halen, Franz Liszt, Nikolai Rimski-Korsakov, Aleksandr Scriabin, Amy Beach, Nabokov, Faulkner, Virginia Woolf, Joyce, Huysmans, Baudelaire and Dylan Thomas (as cited in Mencher \& Cytowic, n.d., p. 3; Cytowic, 1989; Ackerman, 1990, p. 290). Composer Olivier Messiaen who possesses bidirectional synesthesia—sight and sound go both ways-describes, when composing a piece at Bryce Canyon, Utah, the music as writing itself "as [his] eye went up the canyon walls and that magnificently blue Stellar's Jay flew overhead" (as cited in Mencher \& Cytowic, n.d., pp. 4-5). Messiaen invented his method of composition to convey the colours of sounds, sound he experienced-which to others were "strange clusters of notes," unharmonious in the conventional sense, "not even recognized as chords" (cited in Mencher \& Cytowic, n.d., p. 5). For him, "they sound like colors" (cited in Mencher \& Cytowic, n.d., p. 5) and appear in varying arrangements including colour pairs: blue-violet and red-orange, and also complex colours that are "flecked, hemmed, speckled or studded with other kinds of opalescent colors in them" (cited in Mencher \& Cytowic, n.d., p. 5).

A sense of deep calm spreads through me as I fall into rhythm with the cattle. It is hard to return to the task at handlift the hammer and tap in a new insulator. Insistently, I turn my attention to my hands so to not crack the insulator or hit my thumb.

But I feel them still—and notice a gentle sway in my body as I become with cows, calves, and grass. In taking notice, in being struck, I slipped across the pasture and joined their bovine play. This place, this land, I am. 
In vibrant ways, the experience of synaesthesia, supported by walking pedagogies, contributes to a paradigm shift in the ways we must come to see learning as simultaneously sensorial, textured, vibrational and unpredictable, and as webbed with earthscapes that perform us. Walking supports cross-circuitry of the brain-the synchrony of some variation of lifting the left arm in tandem with lifting the right leg, the right arm with the left leg, coupled with roving eyes. As such, walking demonstrates "circumambulatory knowing" (Ingold, 2004, p. 331) and rhythmic thinking. When we walk with another, the art practice, performative knowing, or "conversive wayfinding" (Myers, 2020, p. 67) creates a "dialogic, relational space" (O'Neill \& Hubbard, 2010, p. 50) between us that becomes an embodied space where "shared viewpoints" and shared "earpoints" (Myers, 2010, p. 61) can facilitate "empathic witnessing" as well as collaborative knowledge production (p. 60). Walking aligns perception, thought, and the world-as if "they were three characters finally in conversation together, three notes making a chord" (Solnit, 2001, p. 5). In walking, we encounter places, enliven them, and in turn, become enlivened. The effect, as Casey (1996) details, is a "place-world that is the correlate of the ambulatory body - a world constituted by the very same body that depends on it for its own ongoing localization" (p. 228). As Wallace Stevens beautifully penned the holon, "I am the world in which I walk" (n.d.).

My eyes catch grit and hair whips my face. Here, it is not the sand that dominates. It is the wind, as it has done for thousands of years. Winds blowing from the north have fashioned sands into enormous dunes, align in parallel with the winds' direction-an appearance akin to the Rockies running from the north along the British Columbian coast to Alberta, through Idaho, Montana, and down into New Mexico. The 4800-kilometre cordilleran backbone of the great upland system replicates these vast dunes, mountainous sand chords, breaking along the great inland sea, breathing each other into being.

I reach a sand sheet, no dunes, only wind-swept sand with little vegetation. 72,000 square $\mathrm{km}$ sand desert, erg, between western Egypt and eastern Libya. We are only 50 kilometres from the Libyan border.

Awareness of this proximity does not dissipate as my eyes search to discern difference in unfamiliar terrain.

An earthy curriculum values senses, embodiment, place, and walking, which extends from and must be informed by relations, reciprocity, and respect. The more fluid boundaries among children, youth, and their surroundings open and extend placeways for learning-and-teaching. Active, attentive participation with placescapes, both outer and inner, can transform how education unfolds. Imaginative, imaginal and creative expression offer children and youth opportunities to maintain internal relations among themselves, the more-than-human-world, mystery, and the not-yet. Gardens, trees, animals, more arts, more movement, more rhythm, and more engagement with families and communities, when placed at the heart of curriculum invite invention, new ideas, and engagement with what is felt, with what can be loved. The world of adult abstraction, of lessons in 
cognitive development that eradicate sensorial experience and the primacy of the body, must be redirected back to the concrete. For educators to prioritize and value children's withness of their bodies, and body as multi-inter-sensory knowing, liberates the ways they know and what they value. Such revisioning acknowledges that our most "vivid apprehensions of value," those which are valuable in themselves, are gained from "aesthetic appreciation" (Whitehead, 1929/1957, p. 40). Too great an emphasis on separation and singularity directs "attention to things as opposed to values" (Whitehead, 1925/1953, p. 202), a method in and legacy of our schools that have robbed the world of much value and life. Walking returns us to earthly relations.

We drive on, deeper into the Sahara. I lick my lips, taste saltnot just mine but the old sea riding the air. Salt foretells Siwa is near.

Nostrils flare and ears crackle, as we descend below sea level. Belly and sight drop to white-crusted sand, the salt pans and salt marshes that cover the deep depression. We have reached the isolated Berber settlement, ancient home of the Oracle of Ammon.

"Tell me the landscape in which you live."

\section{About the Author}

Alexandra Fidyk, PhD, transdisciplinary scholar, serves as professor in the Department of Secondary Education, University of Alberta. Her current research focuses on somatic, contemplative and arts practices in relation to health and trauma.

\section{References}

Abilene. (2018, July 9). Medical discover news: Synthesia may provide clues as to how the brain is wired. Abilene Reporter News. https://www.reporternews.com/story/life/2018/07/09/medicaldiscover-news-synthesia-may-tell-how-brain-wired/764055002

Abram, D. (1996). The spell of the sensuous: Perception and language in a more-than-human world. Vintage.

Abram, D. (2010). Becoming animal. An earthly cosmology. Pantheon.

Ackerman, D. (1990). A natural history of the senses. Vintage.

Anderson, J. (2004). Talking whilst walking: A geographical archaeology of knowledge. Area, 36(3), 254-261.

Barad, K. (2003). Posthumanist performativity: Toward an understanding of how matter comes to matter. Signs: Journal of Women in Culture and Society, 28(3), 801-831.

Basso, K. H. (1996). Wisdom sits in places: Notes on a Western Apache landscape. In S. Feld \& K. H. Basso, Senses of Place (pp. 53-90). School of American Research Press. 
Casey, E. (1996). How to get from space to place in a fairly short stretch of time: Phenomenological prolegomena. In S. Feld \& K. H. Basso (Eds.), Senses of Place, (pp. 12-52). School of American Research Press.

Casey, E. (2001). Between geography and philosophy: What does it mean to be in the place-world? Annals of the Association of American Geographers, 91(4), 683-693.

Cytowic, R. E. (1989). Synesthesia: $A$ union of the senses. Springer.

Feinberg, P. P. (2016). Towards a walking-based pedagogy. Journal of the Canadian Association for Curriculum Studies, 14(1), 147-165.

Fulton, H. (2010). Walk. Visual Studies, 25(1), 8-14.

Gallagher, W. (1993). The power of place: How our surroundings shape our thoughts, emotions, and actions. Harper Collins.

Gasset, J. (2011, November 29). C. C. Benison: The landscape in which I live. National Post. Retrieved from https://nationalpost.com/afterword/c-c-benison-the-landscape-in-which-i-live

Heyrman, H. (2005). Art and synesthesia: In search of the synesthetic experience [Paper presentation]. First International Conference on Art and Synesthesia, Universidad de Almeria, Spain. http://www.doctorhugo.org/synaesthesia/art/.

Horowitz, A. (2013). On looking: Eleven walks with expert eyes. Scribner.

Ingold, T. (2010). Footprints through the weather-word: Walking, breathing, knowing. Journal of the Royal Anthropological Institute, S121-S139.

Ingold, T. (2004). Culture on the ground. Journal of Material Culture, 9(3), 315-40.

Ingold, T. (2000). The perception of the environment: Essays on livelihood, dwelling and skill. Routledge.

Irving, A. (2010). Dangerous substances and visible evidence: Tears, blood, alcohol, pills. Visual Studies, 25(1), 24-35.

Irwin, R. L. (2006). Waling to create an aesthetic and spiritual currere. Visual Arts Research, 32(1), 7582.

Jardine, D. (1998). "The fecundity of the individual case": Considerations of the pedagogic heart in interpretive work. In D. Jardine (Ed.), To dwell with a boundless heart: Essays in curriculum theory, hermeneutics, and the ecological imagination (pp. 33-52). Peter Lang.

Judson, G. (2018). A walking curriculum: Evoking wonder and developing sense of place (K-12).

Keller, C. (1996). From a broken web: Separation, sexism, and self. Beacon.

Kabat-Zinn, J. (2005). Coming to our senses: Healing ourselves and the world through mindfulness. Hyperion.

Lippard, L. R. (1997). The lure of the local: Senses of place in a multicentered society. Norton.

Mencher, S., \& Cytowic, R. (n.d.). Music and the brain podcast [transcript]. Library of Congress. https:/ /www.loc.gov/podcasts/musicandthebrain/transcripts/loc_musicanndthebrain_cytowic.pdf

Merleau-Ponty, M. (1962). Phenomenology of perception. Oxford University Press.

Ogg, A. (2020, November 9). "Pleasantdale." Cree Literacy Network. http://creeliteracy.org

Pink, S., Hubbard, P., O'Neill, M., \& Radley, A. (2010). Walking across disciplines: From ethnography to arts practice. Visual Studies, 25(1), 1-7. 
Püschel, A. (2017). Layers of reality. Perception study of a Synaesthete. The Eriskay Connection. Solnit, R. (2001). Wanderlust: A history of walking. Verso.

Springgay, S., \& Truman, S. E. (2019). Walking methodologies in a more-than-human world: WalkingLab. Routledge.

Stevens, W. (2007). Poem of the day: Tea at the palace of Hoon. In N. Alvarez (Blogger) Poem of the Month. https://ninaalvarez.net/2007/05/04/poem-of-the-day-50/ (First published in 1921)

Van Campen, C. (2009). The hidden sense: On becoming aware of synaesthesia. http://www.daysyn.com/vanCampen2009.pdf

Weil, S. (1947/1999). Gravity and grace. Routledge.

Whitehead, A. N. (1953). Science and the modern world. The Free Press. (First published in 1925)

Whitehead, A. N. (1941). Process and reality. The Free Press. (First published in 1929)

Whitehead, A. N. (1957). The aims of education. The Free Press. (First published in 1929) 